УДК: 33

DOI $10.21661 / \mathrm{r}-118230$

\title{
Ю.В. Соколова
}

\section{ПРЯМЫЕ И ВЕНЧУРНЫЕ ИНВЕСТИЦИИ В РОССИЙСКОЙ ФЕДЕРАЦИИ: ОБЗОР И АНАЛИЗ РЫНКА, ТРЕНДЫ}

Аннотация: в исследуемой статье автором представлен обзор и анализ рынка прямых инвестиций, выявлены основные тренды его развития, сделан вывод о том, что сегмент венчурных инвестиций начинает занимать все более существенную долю рынка прямых и венчурных инвестищий.

Ключевые слова: прямые инвестиции, венчурные инвестиции, фонд прямых инвестиций, венчурный фонд.

\section{J.V. Sokolova}

\section{MARKET OF PRIVATE EQUITY AND VENTURE CAPITAL INVESTMENTS IN RUSSIAN FEDERATION: OVERVIEW AND ANALYSIS, MAIN TRENDS}

Abstract: in the article the author gives an overview and analysis of Russian private equity and venture capital market and identifies the main trends of its development. It is also summarized that the segment of venture investments starts to play more significant role in the market of direct and venture investments.

Keywords: private equity investments, venture capital investments, private equity fund, venture fund.

В условиях рецессии российский рынок прямых и венчурных инвестиций продолжает сжиматься по всем показателям: снижается совокупный капитал действующих фондов прямых и венчурных инвестиций и инвестиционная активность, что следует из статистических данных об уменьшении совокупного объема прямых и венчурных инвестиций, числа сделок и активных на российском рынке фондов прямых и венчурных инвестиций. 
Согласно прогнозу Мирового Банка, снижение реального ВВП Российской Федерации в 2015 г. составило -3,7\%, в 2016 г. ожидается замедление падения ВВП по -1,9\%. С 2014 г. резко сократился приток прямых иностранных инвестиций (ПИИ) в экономику России, так в 2013 г. ПИИ в РФ составили 69,2 млрд долл., в то время как в 2014 г. этот показатель снизился на 68\%, достигнув 22 млрд долл., в 2015 г. - до рекордно низкого объема в 6,5 млрд долл. В первом полугодии 2016 г. наметились тенденция сокращения темпов падения ПИИ относительно докризисных уровней: в российскую экономику проинвестировано 6,7 млн долл. ПИИ.

Снижение цен на сырьевые ресурсы, девальвация национальной валюты, стагнация экономики, ухудшение инвестиционного климата и неразвитость инновационной экосистемы - все эти факторы являются основными причинами снижения активности на рынке прямых и венчурных инвестиций.

Характерным является тот факт, что Европейский Банк Реконструкции и Развития (ЕБРР) с июля 2014 г. прекратил финансирование проектов в России. ЕБРР как институт развития являлся важным инвестором ряда фондов прямых инвестиций и осуществлял прямые инвестиции самостоятельно, в 2013 г. ЕБРР вложил в российские проекты 1,8 млрд евро, всего же с 1991 г. по 2013 г. банк вложил в российские проекты более 25 млрд. евро. Санкции продолжают негативно влиять не развитие сегмента прямых и венчурных инвестиций. ЕБРР объявил, что в 2017 г. инвестиции в РФ не планируются, лимиты на РФ могут перераспределяться на фонды других стран СНГ .

В свете ухода с рынка ЕБРР заменой оказались фонды с государственным участием. В последние годы Российский Фонд Прямых Инвестиций (РФПИ) стал активным участником рынка: так с даты основания фонда в 2011 г. РФПИ инвестировал 860 млрд руб. в более чем 30 проектов, из которых лишь 92 млрд руб. средства самого РФПИ, остальные финансовые ресурсы - средства соинвесторов, партнеров и банков. С целью развития индустрии и привлечения международных инвестиций в экономики страны РФПИ создает международные партнерства, такие как, например, Российско-китайский инвестиционный фонд 
(РКИФ) с капиталом 2 млрд долл., совместный фонд с Mubadala объемом 2 млрд долл. Так в 2016 г. РФПИ осуществил такие крупные инфраструктурные сделки, как инвестиции в Международный аэропорт Владивостока (31,5 млн долл.), Контейнерный терминал НУТЭП (32,3 млн долл.), складские комплексы Шереметьево и Чехов-3 (50 млн долл.), а также компании Эфко (75 млн долл.) и АФГ Националь (70 млн долл.), РКИФ приобрел долю в ОАО «Детский мир» за 133,7 млн долл.

Совокупный капитал действующих на российском рынке фондов прямых и венчурных инвестиций по состоянию на конец 3 квартала 2016 г. составил 21,1 млрд долл. (-7,1\% по сравнению с 2015 г.). В 2012 и 2013 гг. наблюдался достаточно существенный прирост капитала под управлением фондов прямых и венчурных инвестиций на $21,8 \%$ и $8,5 \%$ соответственно. В 2015 г. рост в секторе прямых и венчурных инвестиций сменился значительным оттоком капитала на $-13,7 \%$ по сравнению с 2014 г., замедлившимся в 2016 г. до -7,1\% по сравнению с прошлым годом.

Немаловажно отметить, что доля венчурных фондов в совокупном объеме капитала прямых и венчурных фондов неуклонно росла, достигнув 19,4\% по состоянию на конец 3 кв. 2016 г. в сравнении с 15,8\% на конец 2012 г. Кроме того, темпы прироста капитала венчурных фондов в 2012-2013 гг. значительно опережали темпы прироста капитала под управлением фондов прямых инвестиций. За период 9 мес. 2016 г., несмотря на снижение совокупного капитала под управлением прямых и венчурных фондов на 7,1\% и снижением капитала под управлением фондов прямых инвестиций на -9,4\%, венчурные фонды продемонстрировали рост капитала под управлением на 4,2\% по сравнению с прошлым годом. 


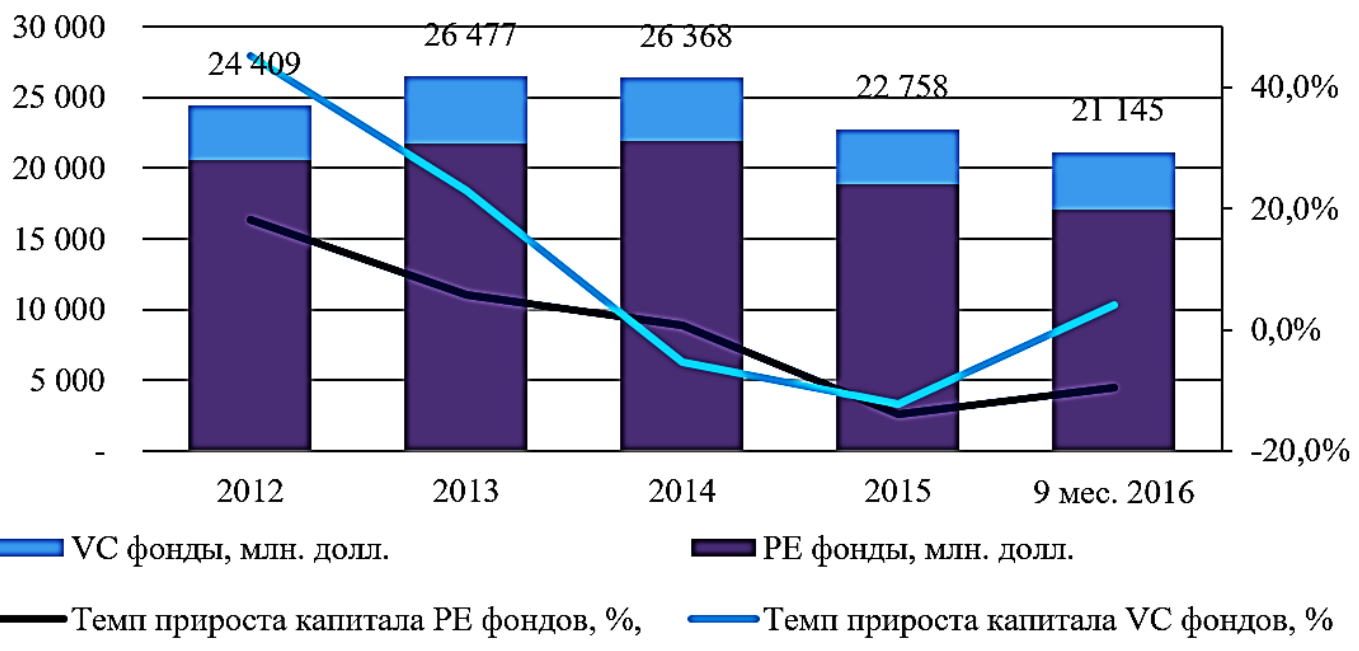

Рис. 1. График 1. Совокупный капитал действующих

VC и РЕ фондов, млн долл.

Источник: Обзор рынка прямых и венчурных инвестищий РАВИ за 9 мес. 20162.

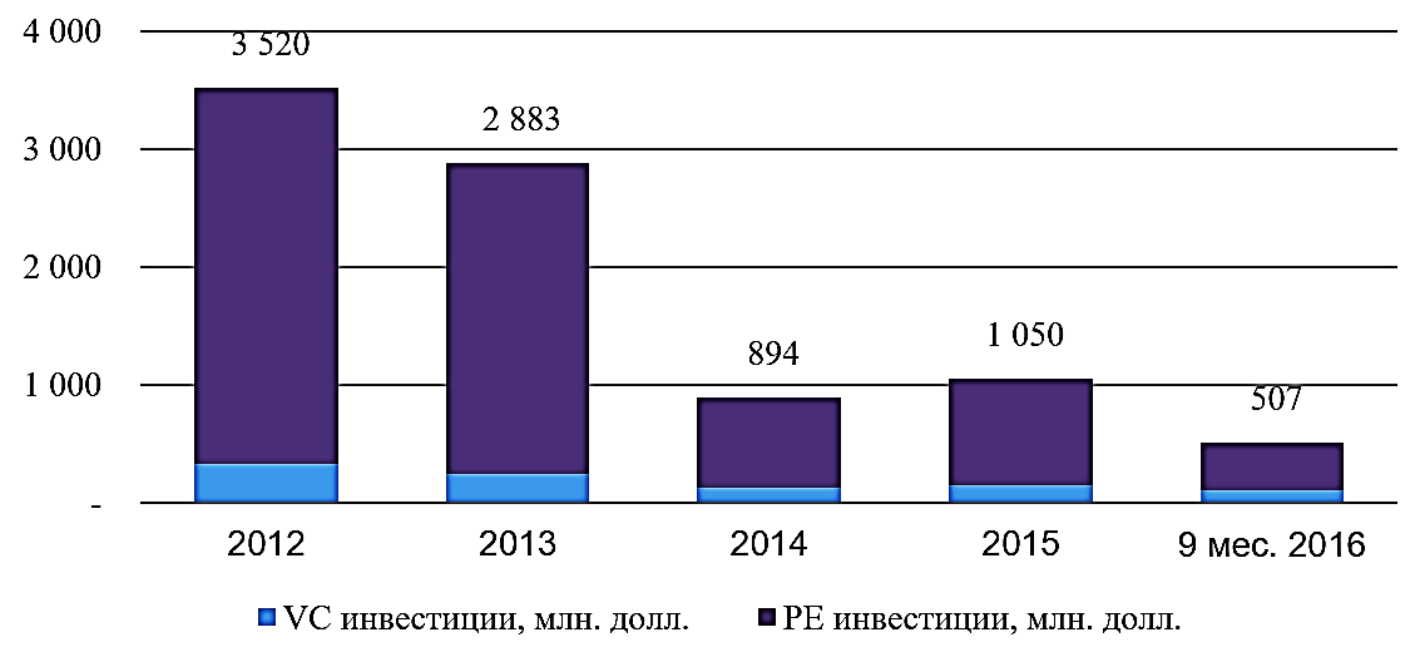

Рис. 2. График 2. Совокупный объем VС и РЕ инвестиций, млн долл.

Источник: Обзор рынка прямых и венчурных инвестиций РАВИ за 9 мес. 20162.

На протяжении последних лет наблюдается падение совокупного объема прямых и венчурных инвестиций, обусловленное снижением активности в сегменте фондов прямых инвестиций. Так совокупный объем прямых и венчурных инвестиций продемонстрировал существенное снижение с 3520 млн долл. в 2012 г. до 894 млн долл. в 2014 г. (-74,6\%), стабилизировался и даже показал 
прирост на 17,4\% в 2015 г., хотя и сравнительно с низкой базой 2014 г. Показатели совокупного объема прямых и венчурных инвестиций за 9 мес. 2016 г. также свидетельствуют о снижении инвестиционной активности на рынке.

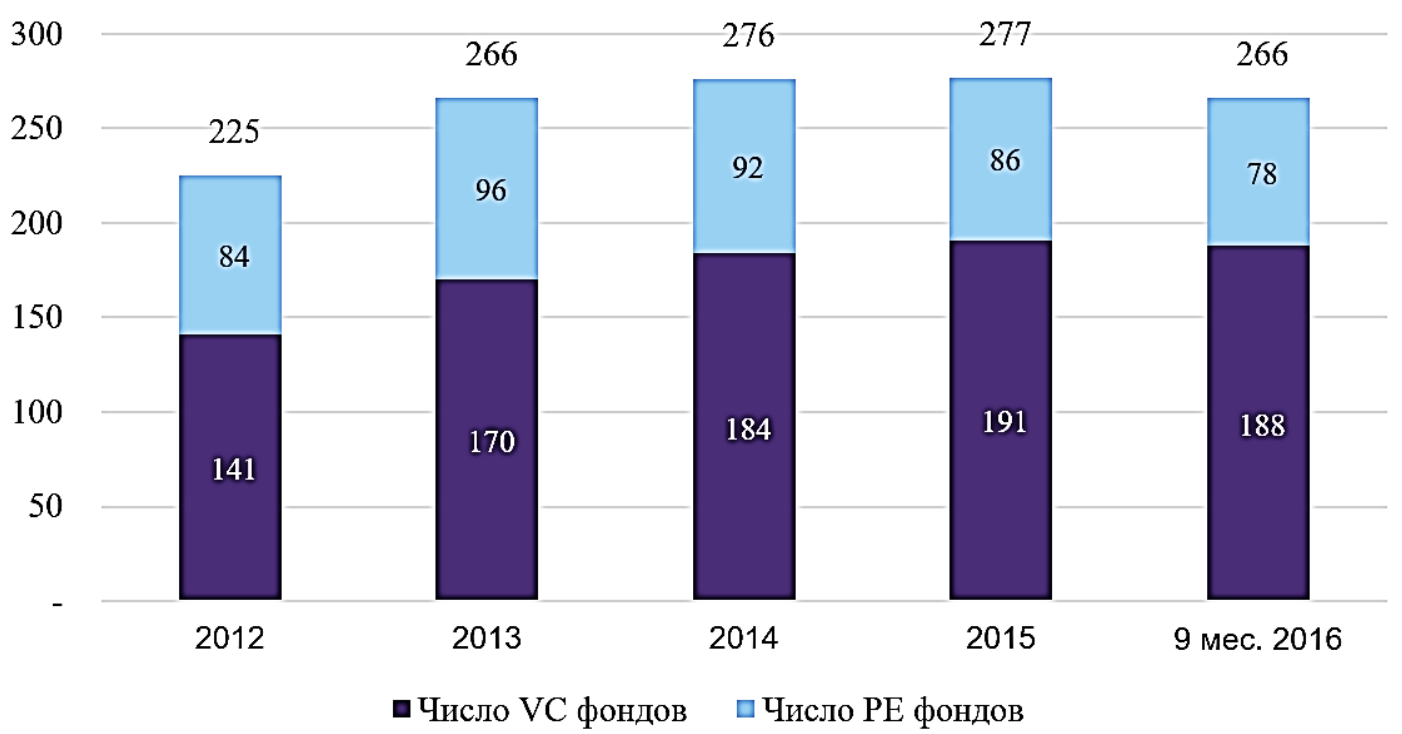

Рис. 3. График 3. Совокупное число действующих VC и РЕ фондов

Источник: Обзор рынка прямых и венчурных инвестищий РАВИ за 9 мес. 20162.

Вместе с тем совокупное число инвестиций фондов прямых и венчурных инвестиций снижается не столь драматично, что связано с активностью венчурных фондов, бурный рост числа которых отмечался в 2013-2014 годах, достигнув максимального значения в 2014 г. - 257 сделок.

Общее число инвестиций по итогам 2015 года уменьшилось на 23,7\% от уровня 2014 года - 196 инвестиций (из них 183 - венчурные инвестиции) против 257 в 2014 году. Существенный вклад в поддержание указанных показателей на относительно высоком уровне внесли государственные или около государственные структуры. За 9 мес. 2016 г. произведено 145 сделок, из которых всего 4 сделки прямых инвестиций и 141 венчурных сделок.

Количество и размер сделок с участием фондов прямых инвестиций неуклонно сокращается, заменить в некоторой степени смогут фонды с государственным участием, такие как РФПИ, ВЭБ, Роснано. 


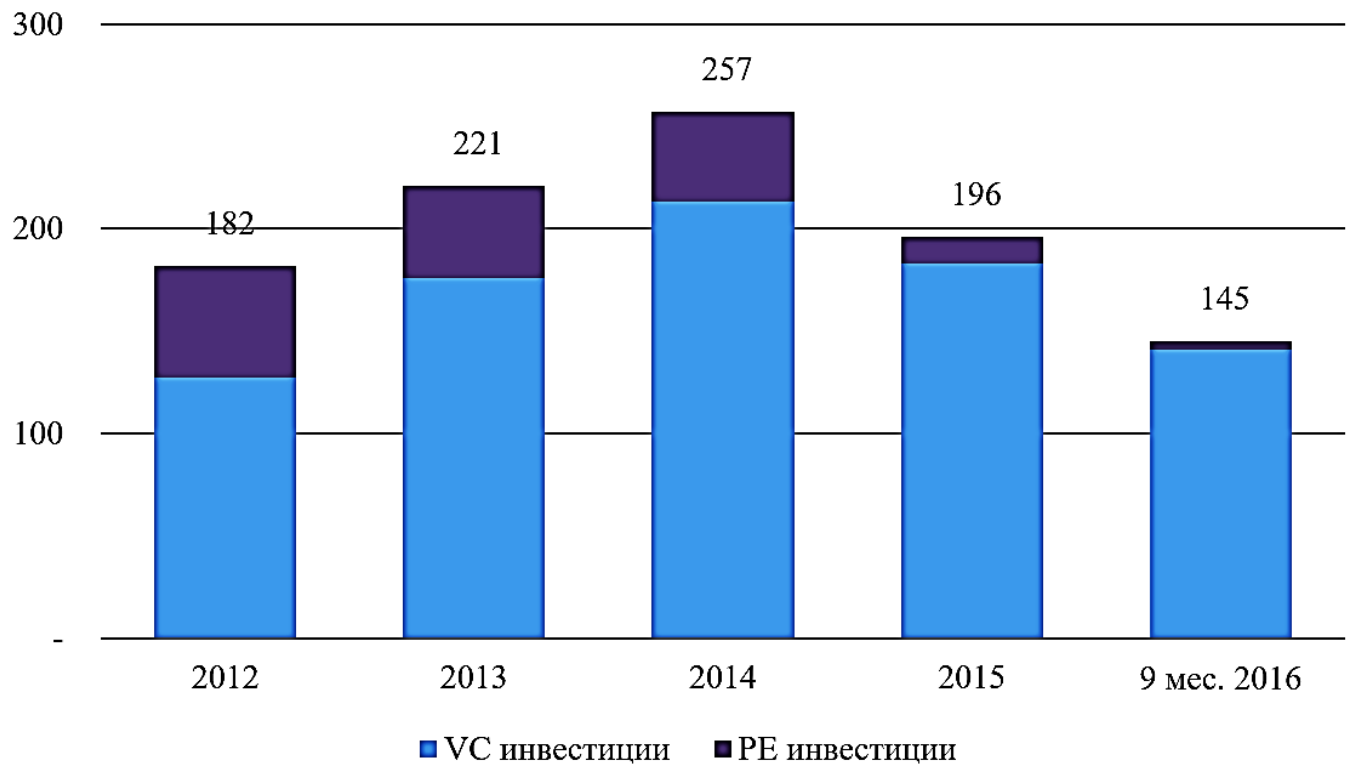

Рис. 4. График 4. Совокупное число VС и РЕ инвестиций

Источник: Обзор рынка прямых и венчурных инвестиций РАВИ за 9 мес. 20162.

За период 2012 - 9 мес. 2016 гг. доля венчурных фондов от совокупного числа и капитала действующих фондов имеет тенденцию к медленному росту с $62,7 \%$ до 70,7\% по числу фондов и с $15,8 \%$ до 19,4\% по объему капитала.

Тенденцией развития рынка прямых и венчурных инвестиций является возросшая активность венчурных фондов, в то время как развитие сегмента фондов прямых инвестиций демонстрирует обратную тенденцию к снижению рыночной активности. Так за период 2012-9 мес. 2016 гг. число венчурных сделок кратно возросло с 30,2\% до 97,2\%. Однако в силу того, что средний размер инвестиции фондов прямых инвестиций значительно выше среднего объема венчурных сделок, в совокупном объеме инвестиций с долей 79,3\% по-прежнему превалируют фонды прямых инвестиций. Тем не менее, доля фондов прямых инвестиций в совокупном объеме инвестиций снижается с 90,6\% в 2012 г. до 79,3\% по состоянию на конец 3 кв. 2016 г. 


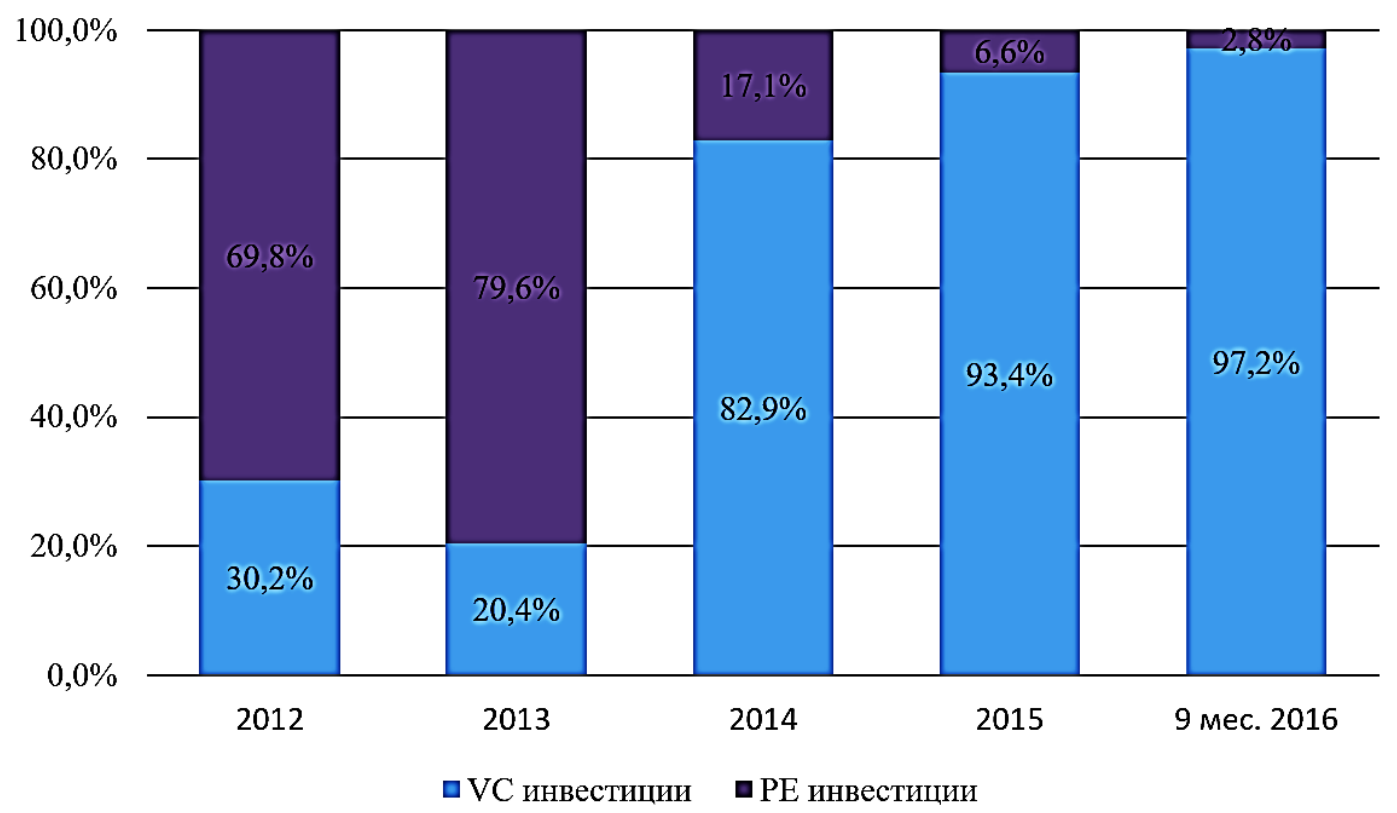

Рис. 5. График 5. Доля VC и РЕ инвестиций в совокупном числе инвестиций

Источник: Обзор рынка прямых и венчурных инвестиций РАВИ за 9 мес. 2016 г.

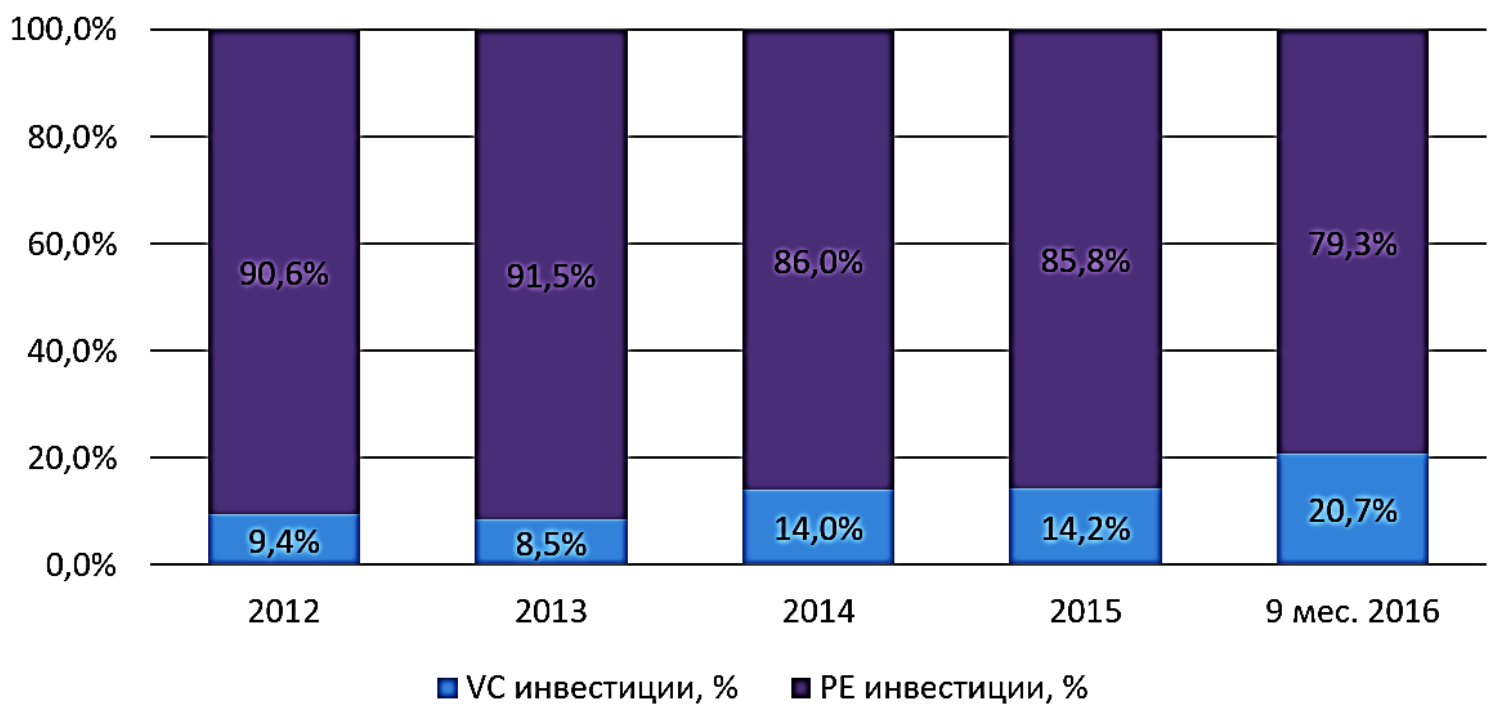

Рис. 6. График 6. Доля VC и РЕ инвестиций в совокупном объеме инвестиций

Источник: Обзор рынка прямых и венчурных инвестиций РАВИ за 9 мес. 20162.

В условиях драматического снижения объема инвестиций на рынке прямых и венчурных инвестиций тенденцией является снижение среднего размера инвестиций (с 19,3 млн долл. до 3,5 млн долл. в 2016 г.). Из-за резкого обесценения 
рубля к основным валютам в 2015-2016 гг. значительно снизился средний размер новых фондов, кроме того сказывается отсутствие на рынке крупных западных инвесторов, таких как ЕБРР.

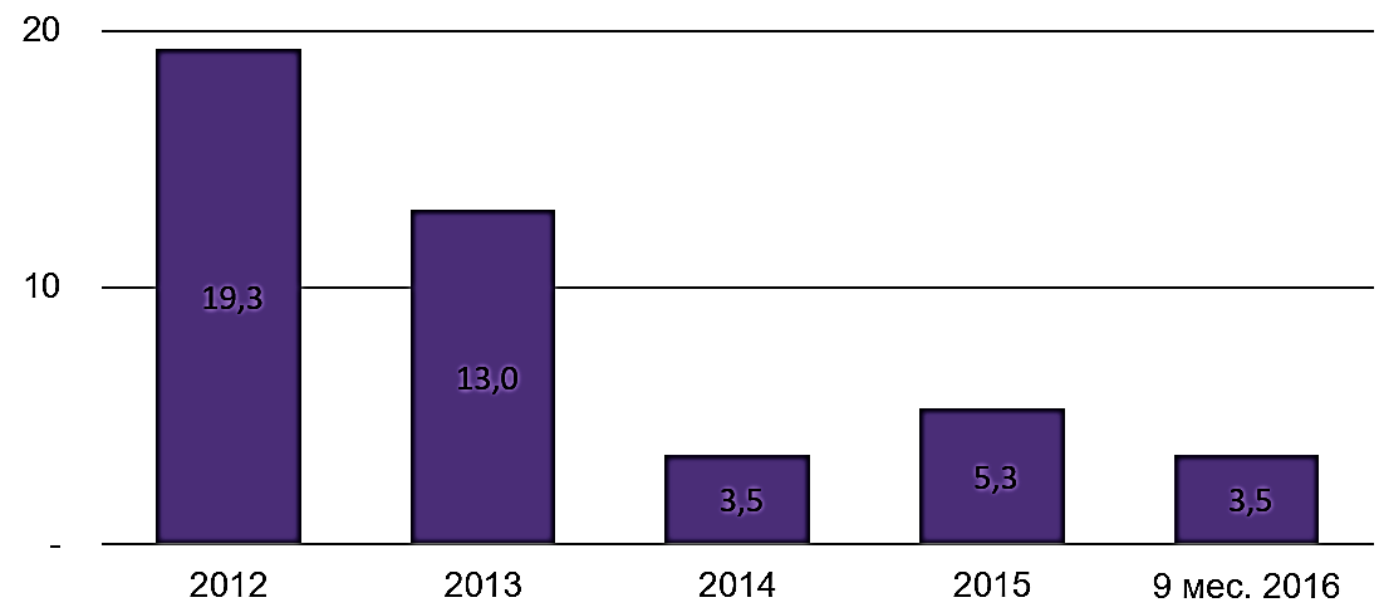

Рис. 7. График 7. Средний объем VС и РЕ инвестищий, млн долл.

Источник: Обзор рынка прямых и венчурных инвестиций РАВИ за 9 мес. 20162.

В секторе венчурных инвестиций явно наметились отраслевые диспропорции, что коррелирует с глобальными трендами развития экономики: свыше $30 \%$ отраслевых предпочтений, заявленных действующими фондами прямых и венчурных, относится к сектору информационно-коммуникационных технологий (ИКТ). Также наблюдается рост интереса венчурных фондов к отраслям, связанным с разработкой реальных технологий (биотехнологий, медицины и здравоохранения, химических материалов).

ИКТ сектор превалирует в сегменте прямых и венчурных инвестиций как по числу, так и по объему инвестиций (в 2016 г. 78,6\% от общего числа инвестиций, благодаря активной работе ряда «серийных» фондов посевных инвестиций, доля по объему венчурных инвестиций составляет 51,2\%). 


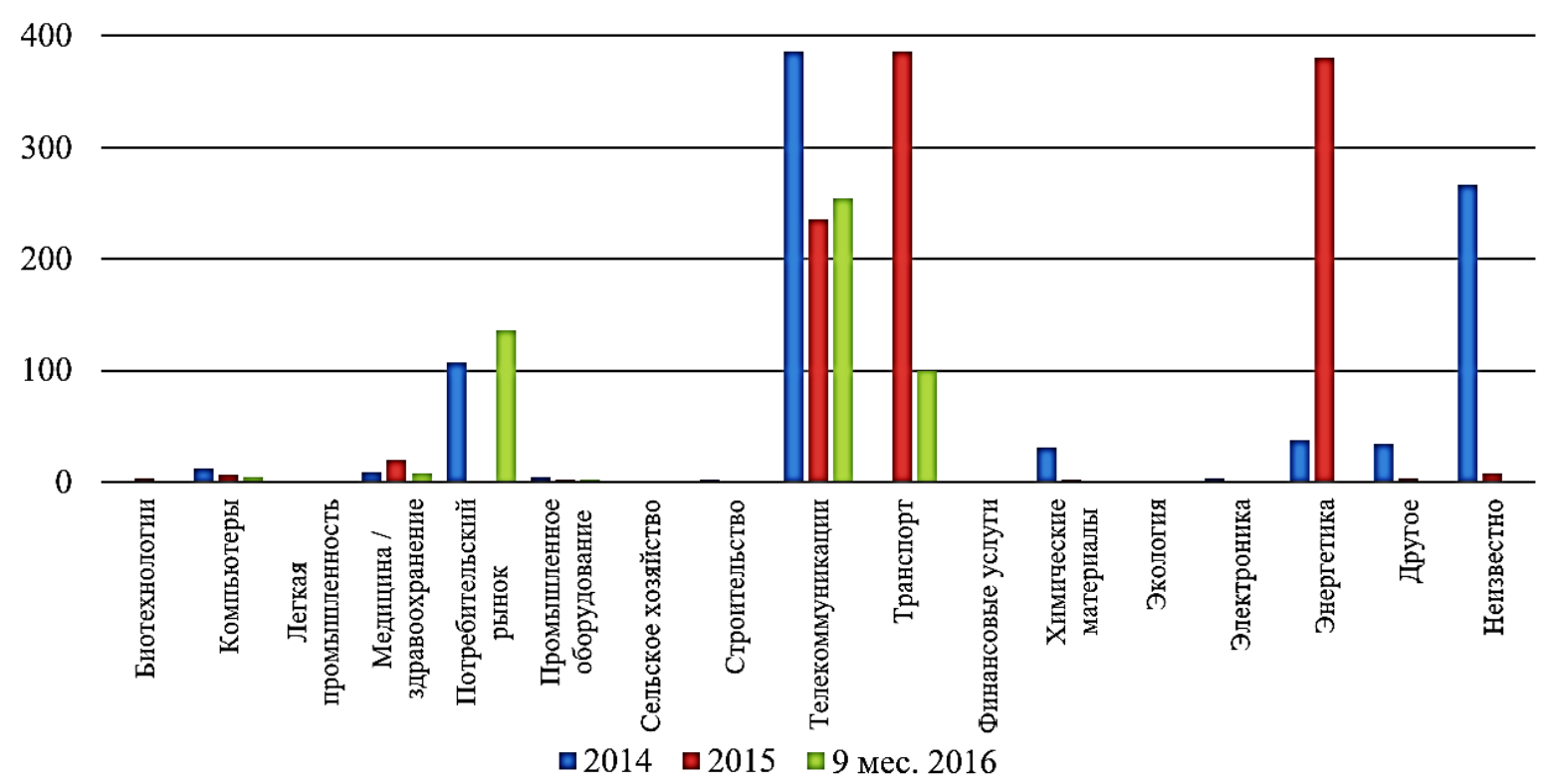

Рис. 8. График 8. Объемы РЕ и VС инвестищий по отраслям, млн долл.

Источник: Обзор рынка прямыхх и венчурных инвестиций РАВИ за 9 мес. 20162.

Отраслевое распределение объема инвестиций в целом коррелирует с инвестиционным фокусом действующих фондов прямых и венчурных: лидирует сектор ИКТ (объединяющий отрасли телекоммуникаций и информационных технологий).

Рост объемов инвестиций в таких секторах, как транспорт и энергетика связан с активностью в сфере инфраструктурных проектов РФПИ (сделки по приобретению долей: Терминал СУГ в порту Усть-Луга, Международный аэропорт Владивостока, ОАО Детский мир, складские комплексы PNK-Северное Шереметьево, PNK-Чехов 3), а также сделок других фондов прямых инвестиций (сделки по приобретению долей: Интер РАО ЕЭС, 2ГИС, CarPrice, HeadHunter) и т. д.

Следствием неблагоприятных экономических условий является «замораживание» или откладывание выходов фондов из проектов, о чем свидетельствует статистика совокупного объема выходов из портфельных компаний: снижение с 4 800,2 млн долл. в 2013 г. до практически нулевой отметки в 2016 г. С 2015 г. увеличилось число сделок с проблемными активами (безденежные сделки, списания, переход в собственность за долги и др.). 


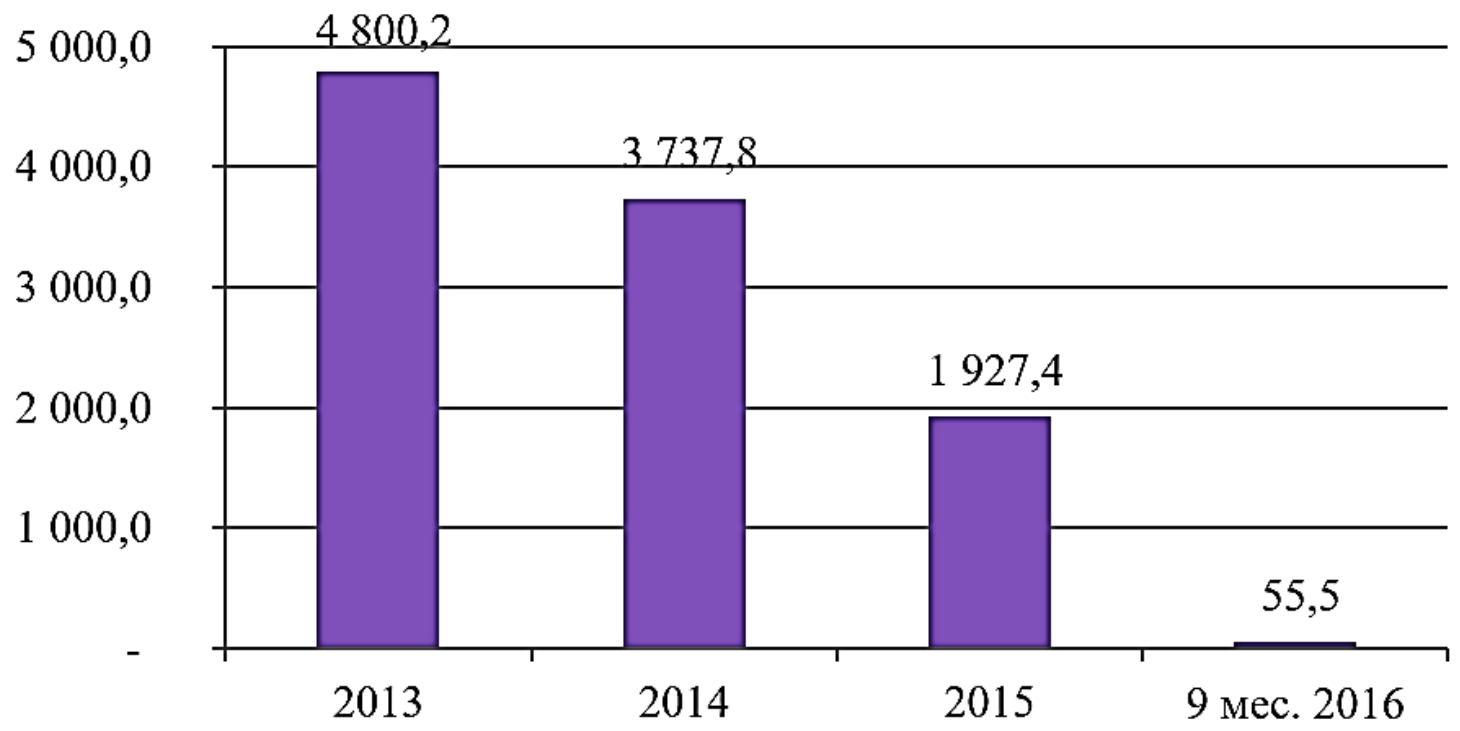

Рис. 9. График 9. Совокупнный объем выходов фондов прямых и венчурных инвестиций из российских компаний-реичпиентов, млн долл.

Источник: Обзор рынка прямых и венчурных инвестиций РАВИ за 9 мес. 20162.

Резюмируя, можно сделать вывод о том, что на динамике таких показателей рынка прямых и венчурных инвестиций, как совокупный капитал под управлением, совокупный объем инвестиций, число действующих фондов и число сделок, средний размер сделки и размер фонда, негативным образом сказываются макроэкономические кризисные явления, что особенно заметно в сегменте прямых инвестиций. Тем не менее, сегмент венчурных инвестиций, заметно активизировавшийся, начинает занимать все более существенную долю рынка прямых и венчурных инвестиций, а меры государственной поддержки прямых и венчурных инвестиций становятся все более очевидными.

\section{Список литературы}

1. Обзоры рынка прямых и венчурных инвестиции в России за $2014-9$ мес. 2016 гг.- Российская Ассоциация Прямого и Венчурного Инвестирования [Электронный pecypc].

Режим доступа: http://www.rvca.ru/rus/resource/library/rvca-yearbook/ 16.01.2017). 
2. Ежемесячный аналитический бюллетень PREQVECA monthly PREQVECA [Электронный pecypc]. - Режим доступа: http://www.preqveca.ru/preqveca_monthly/ (дата обращения: 05.02.2017).

3. World Bank report: The long journey to recover. Russia economic report. April 2016. - №35 [Электронный pecypc]. - Режим доступа: http://documents.worldbank.org/curated/en/657991467989516696/pdf/104825-NWPP156290-PUBLIC-WB-RER-No-35-FINAL-ENG.pdf (дата обращения: 16.01.2017).

4. Статистика внешнего сектора [Электронный ресурс]. - Режим доступа: http://www.cbr.ru/statistics/?prtid=svs

5. ЕБРР не планирует размораживать инвестиции в Россию [Электронный pecypc].

Режим доступа: http://www.vedomosti.ru/economics/articles/2016/10/25/662270-ebrr-investitsiirossiyu

6. Российский фонд прямых инвестиций [Электронный ресурс]. - Режим доступа: https://rdif.ru/About/

Соколова Юлия Витальевна - канд. экон. наук, ассистент департамента «Корпоративные финансы и корпоративное управление» ФГОБУ ВО «Финансовый университет при Правительстве Российской Федерации», Россия, Москва.

Sokolova Julia Vitalievna - candidate of economic sciences, assistant of "Corporate Finance and Corporate Governance" Department FSEBI of HE "Financial University under the Government of the Russian Federation”, Russia, Moscow. 